\title{
The Equity Home Bias: Explanations and Financial Anomalies
}

\author{
Imtithel SENDI (corresponding author) \\ Faculty of Economic and Management Sciences- Tunis- Tunisia \\ International Finance Group of Tunisia \\ Avenue Hassan Ibn Thabet Doualy Gafsa 2143- Tunisia \\ Tel: 216-98-698-464Ｅ-mail: imtithel_sendi@yahoo.fr
}

Makram BELLALAH

Université de Picardie - Jules Verne

CRIISEA Pôle Universitaire Cathédrale,10, Placette Lafleur BP 271680027 - AMIENS CEDEX 1 France

Tel : 03- 4406-88 $81 \quad$ E-mail : Makram.bellalah@u-picardie.fr

\begin{abstract}
Financial theory suggests that, in order to reduce portfolio risk, investors should hold nationally and internationally well diversified portfolios. However, investors still overweight their portfolios with the domestic assets. This is referred to as 'the equity home bias'. Many researchers tried to explain this phenomenon by using imperfections on capital markets such as transaction costs, asymmetric information, exchange rate risk etc., but they did not succeed in showing how financial decisions are truly made. This may be due to restrictive assumptions of capital asset pricing models. In this paper we present a survey of some effects of market imperfection on international portfolio choice as well as some limits of these models.
\end{abstract}

Keywords: International portfolio diversification, The equity home bias, International Capital Asset Pricing Model, Financial Anomalies

\section{Introduction}

During the past 20 years, several countries have lifted a large number of their investment restrictions. The national financial markets deregulation and the liberalization of international capital flows have fostered trading in assets abroad. In addition, most of the theory of international portfolio choice predicts that international and global diversification does better than the diversification at the national level and it increases emphasis on emerging markets (Solnik (1974a), De Santise and Gerard (1997), Errunza (1977) among others). Recently, Arouri (2005) develops an asymmetric extension of multivariate GARCH model of De Santise and Gerard (1997, 1998) in order to test the conditional international Capital Asset Pricing Model version. The author estimates the model in the period of March 1973 to March 2003 using four developed markets and three emerging ones. Results show that risk premium betas and correlations vary with the different dates and have different responses to the different shocks. Covariance risk price is modelled with a vector of macroeconomic and financial variables. Then, Arouri (2005) derives an ex ante measure of international portfolio diversification gains. He proves that capital market integration do not reduce portfolio diversification benefits. Gains from international portfolio diversification are significantly positive for all markets especially for the emerging ones.

However, most investors still invest largely at home. This is referred to in international finance as the 'equity home bias'. This violation of standard theories of portfolio choice was documented first by French and Poterba (1991), Tesar and Werner (1995) and then by Bellalah Ma. And Bellalah Mo. (2006). Many theoretical and empirical researchers use market frictions to give plausible explanations to the international diversification puzzle. However, these works do not succeed in explaining the true investors' behaviour. This can be due to restrictive assumptions of capital asset pricing models. In fact, most researches do not take into account the heterogeneity, the irrationality and psychology of investors. In this paper we review different explanations of the puzzle and then we discuss the limits of the traditional theory. In the section 2, we document the equity home bias in the world. The third section represents the capital asset pricing models with frictions as well as other home bias explanations. In section 4, we discuss the limits of the traditional theory in explaining the investors' reticence to portfolio diversifications. Finally, in the last section we conclude.

\section{Documenting the equity home Bias:}

Though international portfolio diversification appears to be the best strategy permitting the reduction of the portfolio risk, investors still overweight their portfolios with the domestic assets. The bias in favour of home 
country equity is illustrated in Charts 1-39 in the appendix. They plot the percentage of domestic stocks in equity portfolios, the world market share and the home bias in seventeen developed markets and twenty-two emerging markets from 1996 to 2007 (data are obtained from International Federation of stock exchanges). The equity home bias represents the difference between the domestic share (which is equal to the total value of domestic companies share trading divided by the total value of the domestic and foreign companies share trading) and the market capitalisation (which is equal to the total domestic capitalization divided by the world market capitalization).

Thanks to international portfolio diversification, domestic investors can construct a portfolio of equities that has less risk. When there are no barriers to international portfolio investments and where investors in all over the world are assumed to be the same, they hold the same portfolio of risky assets, namely the global market portfolio. Adding the hypothesis of market clearing, domestic investors of each country of the world should hold portfolio in which its country shares are equal to its shares in world market capitalization (French and Poterba (1991)). For example, in 2006, investors' portfolios should contain 30\% U.S. stocks since US market represent $30 \%$ of the world market capitalization during this period.

From the appendix 1, we conclude that the home bias is large for the developed countries but in different levels. Asian developed markets of our sample have the highest home bias. It maintained the same level from 1996 to 2007 and they are above 90\%. The lowest home bias level is in the Great Britain it did not exceed 52\%. It is topped by the United-States (it did not exceed $57 \%$ and $68 \%$ ). This can be explained by the financial integration of these two countries.

From the appendix 2, investors from emerging countries are still reticent to international diversification. For the emerging American markets, the highest home bias is in Brazil and Chile, it maintained the same level form 1996 to 2007 and it is about 100\%. For Argentina, Mexico and Peru, the domestic share has known a relative decrease from 2004 to 2007, reaching 66\% in Argentina in 2007. However, in the emerging European and Asian countries investors still hold all their wealth in the domestic market (the domestic shares are about $99 \%$ from 1996 to 2006). Finally, in Africa we have different investors' preferences. The Egyptians still manifest a net preference to domestic assets, but the home bias in South Africa is lower and reached 72\% in 2007. Even though, the domestic shares, in South Africa, are still extremely high relative to the predicted domestic shares, but they are less important than those of some developed markets.

In this way, portfolios are still so far from the optimal diversification level as recommended by modern financial theory. Indeed, despite the liberalization of capital markets and the gains provided by international diversification, investors still underweight their portfolios with foreign assets.

\section{Traditional Home Bias Explanations}

Many authors try to explain the home bias puzzle by market frictions such as the effect of exchange rate risk, transaction costs, restrictions on foreign ownership and asymmetric information. This section gives a survey on the different bias explanations.

\subsection{Direct home bias determinants}

There are several home bias determinants. From then on, we will distinguish between three causes, namely, the hour-shifting, institutional barriers and regulation barriers.

\subsubsection{The Hour-shifting:}

The first explanation of the home bias barrier is the hour-shifting. It is extremely sensitive and difficult for an agent to invest abroad. The first difficulty depends on the diurnal characteristic of economic agents. This psychological limit reduces the investor efficiency in geographically far markets. Actually, at any time in the world there are many closed financial markets, and even though investors have the available information set about assets, they cannot optimally manage and hold a global portfolio.

\subsubsection{Institutional Barriers}

It follows from different empirical studies an approach of home bias phenomenon holding that markets are segmented. Transaction costs, taxes and deadweight costs are important frictions that affect both asset prices and portfolio choice of international investors. Under this form of market imperfection, general and complex asset pricing relations have been emerged, namely, Black (1974), Stulz (1981), Cooper and Kaplanis (1995) and Lewis (1999). These works suggest that the home bias observed in international markets is explained by the effect of these costs preventing some investors from investing in some foreign markets. 
In some overseas, foreign investors are more heavily taxed than domestic investors. In his pioneering work on international finance, Black (1974) modelled a world with different tax rates across national borders. He develops a two country-model when there are explicit barriers to international investments in the form of a tax.

$$
E\left(R_{i}\right)-R-\tau_{i}=\beta_{i}\left(E\left(R_{M}\right)-R-\tau_{m}\right)
$$

Where $\widetilde{R}_{i}$ is the return on security $i ; R$ is the riskless asset in the reference currency; $R_{M}$ is the rate of return of global market portfolio; $\tau_{i}$ the weighted average of tax rates applied to asset $i ; \tau_{m}$ the weighted average tax over all assets in the international markets; and $\beta_{i}=\frac{\operatorname{cov}\left(R_{i}, R_{M}\right)}{\operatorname{Var}\left(R_{M}\right)}$ is the sensivity of the asset $i$ to the market portfolio.

Black (1974) proves that transaction costs have the potential in explaining the equity home bias and shows that the heavily taxed investors tend to invest in their domestic markets. However, he does not take into account the currency risk. He introduces a cost in the form of taxes that differentiate domestic from foreign investment. In this case international markets are segmented and the tax affects the expected rate of return on asset $i$ and decreases the risk premium. Consequently, the market segmentation reduces the gain from international diversification and the international investor prefers investing heavily in the domestic country.

Stulz (1981b) relaxes some restrictive assumptions of the model of Black (1974). He develops a model of international asset pricing in which there is a cost associated with holding either long or short risky foreign assets. He considers that the investment taxation varies with countries and assets. In fact, he supposes that only domestic investors face barriers to international investments. The same asset can be priced differently for domestic and foreign investors. For domestic assets when there is no tax imposed, Stulz (1981b) shows that the domestic assets are priced in context of market integration. In equilibrium, the asset pricing model of the domestic assets is as follow:

$$
E\left(R_{i}\right)=R+\beta_{i}\left(E\left(R_{M}\right)-R\right)
$$

For the foreign assets, the presence of tax generates a segmentation of markets. The author develops the following equation:

$$
\begin{gathered}
E\left(R_{i}\right)=R+\beta_{i}\left[E\left(R_{M}\right)-R\right]+\varepsilon_{i} \\
\text { Where } \varepsilon_{i}=\beta_{i}\left(\tau_{M}+\gamma_{M}\right) A^{D} \tau_{i}-\gamma_{i}^{D}
\end{gathered}
$$

$\tau_{i}$ is the tax imposed on holding the asset $i ; \tau_{M}$ is the average tax on short positions of domestic investors ; $\gamma_{M}$ is the average tax on long positions of the domestic investors; $\gamma_{i}^{D}$ is the tax imposed on the long position of domestic investor on foreign assets; and $A^{D}$ is the domestic investor risk aversion.

If the gains from international diversification do not exceed the costs, $\varepsilon_{i}$, then domestic investors will overweight their portfolios with the foreign assets.

Lewis (1999) extended the model developed by Black (1974). He focused his study on shares and develops a two-country model in which the purchasing power parity holds. In this framework, the tax represents a participation cost to foreign markets. The author shows that taxes decrease the optimal proportion invested by the foreign investors.

$$
\chi_{f}^{t}=\frac{\left(E\left(R_{f}\right)-\tau-E\left(R_{h}\right)\right) / \gamma}{\operatorname{Var}\left(R_{h}-R_{f}\right)}+\frac{\left(\sigma_{h}^{2}-\sigma_{h f}\right)}{\operatorname{Var}\left(R_{h}-R_{f}\right)}
$$

Where $E\left(R_{f}\right)$ is the expected rate of return on the foreign asset; $E\left(R_{h}\right)$ is the expected rate of return on the domestic asset; $\sigma_{f}^{2}$ is the variance of the foreign asset; $\sigma_{h}^{2}$ is the variance of the domestic asset; $\sigma_{h f}=\operatorname{cov}\left(R_{h}, R_{f}\right)$ is the covariance between the rate of return of domestic and foreign asset; and $\gamma$ is the parameter of relative risk aversion.

Lewis (1999) shows that when the costs or taxes $\tau$ increase, the domestic holdings of foreign stocks decrease. At this level, the author proves that the transaction costs explain investors' reticence ti international portfolio diversification.

Cooper and Kaplanis (1994) extend both the model of Adler and Dumas (1983) and the model of Black (1974). They incorporate the inflation risk and the deadweight costs (taxes) imposed on foreign investors. The authors 
show that the inflation rate risk and the differences between the consumption baskets do not explain the home bias. They develop the following equation:

$$
\omega^{*}=\alpha\left[\begin{array}{c}
\Omega^{-1}(\underline{\mu}-r \underline{1}) \\
1-\underline{1}^{\prime} \Omega^{-1}(\underline{\mu}-\underline{1})
\end{array}\right]+(1-\alpha)\left[\begin{array}{c}
\Omega^{-1}(\underline{C}) \\
1-\underline{1}^{\prime} \Omega^{-1}\left(\underline{C}^{j}\right)
\end{array}\right]
$$

Where $\omega^{*}$ is the vector of the optimal proportion of investment in each risky asset; $\Omega$ is the variance-covariance matrix of the instantaneous nominal rate of return; $\mu$ is the vector of expected rate of return; 1 is a vector of ones; and $\underline{C}^{j}$ is a vector of covariance of the asset returns and the inflation risk incorporating the effects of the costs paid by the investors.

Cooper and Kaplanis (1994) estimate the levels of cost required to generate the observed home bias in portfolios. Results show that these costs are consistent with observable costs such as withholding taxes only if investors have low levels of risk aversion.

Following the Obstfeld and Rogoff (2000)'s model, who clamed that by explicitly introducing transaction costs one can explain the major puzzles in international macroeconomics. Carmichael and Coen (2001) use a simple overlapping generation model in order to test whether transaction costs can explain the home bias. They show that in a world without any barrier to international investment, where all is available to induce international diversification, a very low transaction cost (including existing taxes, informational costs, or any other constraint to the international diversification) can generate the home bias observed in portfolio holdings.

In short, the international investment is characterized by the existence of transaction costs, taxes and participant costs. These costs vary from one country to another and from one investor to another. Under these barriers to international investments, the expected rate of return of the same asset is not identical to all investors. So, the international investors will prefer investing in assets with low costs and tend to overweight their portfolios with the domestic assets. These costs have the potential in explaining the home bias and have an important role in international capital budgeting decisions.

\subsubsection{Market Restrictions}

Investor preference to domestic investments seems to be explained by transaction costs. These costs affect both asset returns and investments decisions. In this paragraph we develop another approach considering that there is limitation to foreign ownership and restriction to ownership to specific areas. Absolutely, fund invested internationally fall under the jurisdiction of the host country. Such regulations may appear unfair. As a consequence, these restrictions create market segmentation which prevents some investors to invest abroad. Amir Licht (2001) defined the notion of market segmentation as "a situation where assets having similar profiles of risk nevertheless command different levels of expected return (...)The causes of segmentation -also called investment barriers - isolate markets from one another, thereby enabling return differentials to exist. By doing so, they impede investors from availing themselves of these excess returns. From a social welfare point of view, investment barriers impede efficient allocation of investment capital and lower the total attainable welfare." (Page 569)

He considers that there are three different parameters that characterize segmentation:

- The direction of barriers causing the segmentation, whether they impede inbound or outbound capital flows.

- The degree of segmentation, which measures the difficulty to make a cross-border investment and ranges from zero difficulty to complete prohibition

- The number of countries that implement investment barriers in the world system.

Market segmentation is attributed to restrictions imposed by governments to preserve the control of domestic companies. In this framework, international investors trade the same asset with different prices making them recommend a premium in order to diversify in internationally. Many authors try to model and quantify the impact of market restrictions on asset prices.

Errunza and Losq (1985) develop a two-country model of international asset pricing under mild segmentation. They consider that there are two types of investors. The foreign investors that are unrestricted and can trade on both 'legible' (restricted) and 'ineligible' (unrestricted) assets, and the domestic investors that can trade only in the domestic level. The authors show that the eligible securities are priced as if the markets are integrated:

$$
E\left(R_{e}\right)=R+(A M) \operatorname{cov}\left(R_{e}, R_{M}\right)
$$


Where $E\left(R_{e}\right)$ is the expected rate of return of the eligible asset; $A$ is the risk aversion of all investors given by $A^{-1}=A_{\mu}^{-1}+A_{r}^{-1}$ where $A_{\mu}\left(A_{r}\right)$ is the absolute risk aversion coefficient for the subset of unrestricted (restricted) investors; $M$ : the market value.

Errunza and Losq (1985) argue that the ineligible securities are priced differently. They command a "super" risk premium which is proportional to the conditional market risk:

$$
E\left(R_{i}\right)=R+(A M) \operatorname{cov}\left(R_{i}, R_{M}\right)+\left(A_{\mu}-A\right) M_{I} \operatorname{cov}\left(R_{i}, R_{I} \mid R_{e}\right)
$$

Where $E\left(R_{i}\right)$ is the expected rate of return of the ineligible asset; $\operatorname{cov}\left(R_{i}, R_{I} \mid R_{e}\right)$ is the covariance between the rate of return on the ineligible asset and the market portfolio of the ineligible assets conditioned by the market portfolio of the eligible assets; and $M_{I}$ is the market value of the ineligible assets.

Errunza and Losq (1985) conduct a cross-sectional test of the mild segmentation hypothesis and conclude that the restriction imposed by the foreign government can be an important friction that affects investors' choice and lead them to invest in domestic market rather than internationally. In 1989, Errunza and Losq extended their model developed in 1985 to $N$ countries. They show that the entry of selective barriers can result in a mildly segmented market structure where the equilibrium price of a security is determined jointly by the domestic and the international premiums. The capital flows controls prevent investors from international diversification by holding the world market portfolio. This forces them to acquire nationality-specific portfolios along with a market wide proxy for the world market portfolio. In addition, the removal of investment barriers generally leads to an increase in the aggregate market value. Finally, the authors prove that the introduction of different types of index funds in the international market increase the world market integration and investor welfare. As a result, this tends to favour the international portfolio diversification and to reduce the home bias equity.

Eun and Janakiramanan (1986) derive a closed-form valuation model in two-country world (domestic and foreign). The model in Errunza and Losq (1985) can be seen as a special case of Eun and Jankirmannan (1986) when the proportion of investment in foreign firms is equal to zero. Eun and Janakiramanan (1986) consider that domestic investors are constrained to own at most a fraction, $\delta$, of the number of shares outstanding of the foreign firms while the foreign investors do not face such restrictions on their investments in domestic firms. For foreign securities to which $\delta$ constraint applies, the authors show that there are two different price rules in the foreign security rules in foreign security markets reflecting that the difference between the prices paid by the domestic and foreign for the same assets is explained by the constraint imposed on the domestic investors. These investors are willing to buy a premium, $\pi$, over the price of foreign asset under no restriction, and the foreign investors demand a discount, $\lambda$, over the same price of the foreign asset under no restriction. Then the foreign asset prices for domestic and foreign investors, $P_{F}^{d}$ and $P_{F}^{f}$ are:

$\left\{\begin{array}{l}P_{F}^{d}=P_{F}^{*}+\pi \\ P_{F}^{f}=P_{F}^{*}-\lambda\end{array}\right.$

Where $P_{F}^{d}$ is the price of foreign asset held by the restricted (domestic) investor; $P_{F}^{f}$ is the foreign price for the unrestricted (foreign) investors; $P_{F}^{*}$ is the foreign asset price under no restriction; $\pi$ is the premium paid by the restricted investors; and $\lambda$ is the discount demanded by the unrestricted investors.

The authors prove that the premium the domestic investors are willing to pay is proportional to their aggregate risk aversion measure. The more risk averse the domestic investors are collectively, the higher the premium they would be willing to pay for foreign securities in order to avoid diversification loss.

$$
\pi=\frac{A^{D}}{A^{F}} \lambda
$$

In addition, the theory shows that the equilibrium premium and the discount are determined by both $\delta$ constraint and the "pure" foreign market risk. The more severe $\delta$ constraint, and at the same time the higher "pure" foreign market risk, the higher premium (discount) the domestic (foreign) investors pay. In the other hand, the authors consider that the domestic assets are priced as if the international markets are integrated:

$$
E\left(R_{i}\right)=R+A \operatorname{cov}\left(R_{i}, R_{M}\right) \quad i \in D
$$

$E\left(R_{i}\right)$ :is the expected rate of return of the unrestricted asset. 
Eun and Jankirmannan (1986) show that the presence of a constraint on the foreign assets yields different expected rate of return for the same foreign assets (for the domestic and foreign investors). The expected rate of return for the foreign assets held by the restricted investor is:

$$
E\left(R_{i}^{d}\right)=R+A \operatorname{cov}\left(R_{i}, V_{M}\right)+\left(A-A^{D} \delta\right)\left[\operatorname{cov}\left(R_{i}, V_{F}\right)-\operatorname{cov}\left(R_{i}, V_{A}\right)\right] \quad i \in F
$$

Where $V_{M}, V_{F}$ and $V_{A}$ are respectively the value of the world market portfolio, the value of the foreign market

portfolio and the value of the adjustment portfolio. The expected rate of return of the same foreign asset held by the unrestricted (foreign) investor is:

$$
E\left(R_{i}^{f}\right)=R+A \operatorname{cov}\left(R_{i}, V_{M}\right)-\left(A^{F}(1-\delta)-A\right)\left[\operatorname{cov}\left(R_{i}, V_{F}\right)-\operatorname{cov}\left(R_{i}, V_{A}\right)\right] \quad i \in F
$$

Eun and Janakiramanan (1986) find that the equity home bias can be explained by the different prices paid by the domestic and foreign investors for the same asset. They prove that the domestic investors hold an "adjustment" portfolio of domestic securities that is highly correlated with the foreign market portfolio in order to minimize the diversification loss under the $\delta$ constraint.

Bellalah Ma. (2001) extended Eun and Jankirmannan (1986) model. He develops an international Asset Pricing Model in the presence of a constraint and ownership restrictions in the domestic and the foreign country. He shows that in equilibrium, the domestic and foreign assets are priced differently. Besides, the premiums and the discounts paid and demanded by the investors are proportional to their ratio of risk aversion. The empirical results show that the imposition of the constraint increases the premiums and discounts show that the constraint explains the price dynamics in segmented and integrated markets. The author proves that when the relaxation of the constraint makes markets more integrated. Finally, he concludes that the market segmentation is an important explanation of the home bias.

Hietala (1989) analyzes asset pricing where international markets are segmented and where citizens of a small country are allowed to hold only their domestic securities. Foreign, investors are allowed to hold all securities. Under these assumptions, citizens of the small country are willing to pay less for their domestic securities than are the foreign investors. Hietala (1989) shows the effect of the partial market segmentation and how it affects the expected rate of return and the premium of the same assets. This segmentation explains the bias observed in domestic portfolios.

The author considers that there are two mutually exclusive investor groups: D and F, and there are two types of stocks: set A representing restricted Finnish stocks, set B containing unrestricted Finnish stocks and set $C$ containing all foreign stocks. Hietela Denotes that the opportunity set facing investor $d \in D$ consists of stock in sets $A$ and $B(A \cup B=G)$ and the opportunity set facing investor $f \in F$ consists of stock in sets $B$ and $C$ $(B \cup C=H)$. No investor is allowed to take a short position in any stock in set $A$ or set $B$. Then, Hietela shows that the domestic plane for their investment opportunity set $G$ is:

$$
E\left(\widetilde{R}_{g}\right) \leq R+\frac{\operatorname{cov}\left(\widetilde{R}_{g}, \widetilde{R}_{G^{*}}\right)}{\operatorname{var}\left(\widetilde{R}_{G^{*}}\right)}\left[E\left(\widetilde{R}_{G^{*}}\right)-R\right] \quad \forall g \in G
$$

Where $E\left(\widetilde{R}_{g}\right)$ is the expected rate of return on asset $g ; E\left(\widetilde{R}_{G^{*}}\right)$ is the expected rate of return on the domestic investors' equilibrium portfolio; $G$ refers to domestic investors' investment opportunity set and $G^{*}$ refers to the set of stocks which domestic investors hold in equilibrium; $g$ and $g *$ are generic elements from these sets.

Hietala (1989) splits the last relation in two asset pricing models for assets held by the domestic investors in equilibrium and the assets that are not held in portfolio. The expected rate of return of the assets held by the foreign investors in equilibrium is given by :

$$
\begin{cases}E\left(\widetilde{R}_{h^{*}}\right)=R+\frac{\operatorname{cov}\left(\widetilde{R}_{h^{*}}, \widetilde{R}_{H^{*}}\right)}{\operatorname{var}\left(\widetilde{R}_{H^{*}}\right)}\left[E\left(\widetilde{R}_{H^{*}}\right)-R\right] & \forall h^{*} \in H^{*} \\ E\left(\widetilde{R}_{h}\right) \leq R+\frac{\operatorname{cov}\left(\widetilde{R}_{h}, \widetilde{R}_{H^{*}}\right)}{\operatorname{var}\left(\widetilde{R}_{H^{*}}\right)}\left[E\left(\widetilde{R}_{H^{*}}\right)-R\right] & \forall h \in H-H^{*}\end{cases}
$$


Where $E\left(\widetilde{R}_{h^{*}}\right)$ is the expected rate of return of the asset held by the foreign investor in equilibrium and $E\left(\widetilde{R}_{H^{*}}\right)$ is the expected rate of return of the foreign investors' equilibrium portfolio.

The stocks in sets $H-H^{*}$ which foreign investors do not hold in equilibrium are unrestricted stocks because foreign investors have a positive holding in all foreign stocks. So, the model shows that some unrestricted may sell at prices that are too high from foreign investors' point of view. Hietela concludes that for all assets in sets $A$, $B, C$, there exist two separate risk premiums, one for each investor group evaluating the stock. This fact is not crucial for the assets in sets $A$ and $C$ because they are held in equilibrium by the domestic investors, and assets in set $C$ are held by the foreign investors. However, for the unrestricted assets in set $B$, both risk premiums are relevant because they are held by the domestic and foreign investors. Hietala shows how the partial market segmentation affects the expected rate of return and the premium of the same assets which by its turn can explain the home bias observed in domestic portfolios.

Stulz and Wasserfallen (1995) develop a theory of foreign equity investment restrictions. They consider a model where the demand function for domestic shares differs between domestic and foreign investors. This difference is caused by deadweight costs in holding domestic and foreign securities that depend on the country of residence of investors. They show the existence of a price risk premium for the unrestricted assets. The authors argue that in the presence of differential demands for domestic shares by domestic and foreign investors, firms will want to discriminate between these investors. As a result, this discrimination provides an explanation to help understand why firms sometimes restrict ownership for their shares. The study shows that the price discrimination explains why shares available to foreign investors sell at a premium when there is a home bias in asset holding.

In summary, this kind of market imperfection has the potential in explaining the equity home bias and affects significantly the welfare. It represents a direct determinant of markets restrictions that prevent investors to diversify internationally rather then nationally. In addition to these factors, there are many indirect determinants of international diversification puzzle, namely, macroeconomic risks, the asymmetric information and the human capital.

\subsection{Indirect Home Bias Determinants}

\subsubsection{Macroeconomic risks}

\section{- The Country Risk}

The country risk can be defined as the sinister risk resulting from economic and political context from a foreign country. According to Cosset and Suret (1995) the political risk in business exists "when discontinuities occur in the business environment, when they are difficult to anticipate and when they result from political change" (page 303). The political risk covers in the one hand the internal conflicts such as riots, terrorism, civilian troubles, socio-economic conflicts etc. and in the other hand it covers external conflicts, namely, wars. In addition, we can sit discretionary decisions taken by some governments in order to break up their engagements without judicial recourse, such as the nationalization of the Suez Canal, the nationalizations of oil-industries in the Middle East and in Algeria during the period of 1960-1970 etc. Erb et al (1996) address the economic content of five different measures of country risk, namely, political, financial, economic and composite risk indexes and the country credit ratings. They explore these measures to see whether they contain information about future expected stock returns. The results show the economy risk measures are correlated with future equity returns. As a result, the political risk can affect investment decisions and can explain investors' preference to invest heavily at the domestic level.

- The Financial and the Economic Risk

\section{- Country Financial Situation}

The financial situation implies in particular the liquidity situation and the resulting debt degree of a given country. In other words, the financial situation is the capacity of a country to repay its foreign creditors in the maturity date. There are several ratios indicating the financial situation of a country such as the rapport between exportation and importation. Foreign investors can use these indicators to judge the financial stability of a country and to take the right investment decision.

\section{- $\quad$ Exchange rate risk}

Domestic investors in overseas markets face the exchange risk, namely the risk of their currency appreciation. When profits are repatriated, this appreciation decreases their total return. Solnik (1974), Sercu (1980), Adler and Dumas (1983) and Stulz (1981a) develop models of international asset pricing and study the effect of exchange rate risk and the deviation from purchasing power parity. These models show that the exchange rate 
risk is priced in an international setting and the optimal portfolio for each investor should be the world market portfolio and a personalized hedge portfolio used to reduce the exchange rate risk.

Adler and Dumas (1983) develop an international asset pricing model by assuming that investors in different countries consume different bundles of good. They consider that there are $\mathrm{N}$ countries and currencies. All assets are valuated in nominal units of the $N$ th currency. There are $N$ equity index assets and $N-1$ risky currency asset. Their model proves that every investor in the world holds a combination of the universal logarithmic portfolio with weight $\alpha$ and his personalized hedge portfolio which constitutes the best protection against inflation as he perceives it with the weight $1-\alpha$.

Cooper and Kaplanis (1994) test whether the home bias is caused by investors trying to hedge inflation risk. They develop a model of international portfolio choice and market equilibrium that integrates inflation risk and deadweight costs. They find that for a level of risk aversion consistent with standard estimates of the domestic equity market risk premium, the home bias cannot be explained by either inflation hedging or direct observable costs of international investment unless investors have very low levels of risk aversion.

Vassalou (2000) tests for the pricing of exchange rate and foreign inflation risk in equities. Based on Solnik (1974), Sercu (1980), Grauer et al. (1976) and Adler and Dumas (1983) models, the author shows that both exchange rate and foreign inflation risk factors can explain part of the within-country cross-sectional variation in returns. The results have important implications for hedging exchange rate risk.

The investment at a national level is considered as the best protection against deviation from purchasing power risks and exchange risks. However, recent studies (Cooper and kaplanis (1994), Vassalou (2000)) test this hypothesis. They reject the inflation hedging explanation for the home bias and argue that there are other potential effects of market frictions such as taxes, transaction costs and information costs.

\subsubsection{Asymmetric information}

The perceived differences in languages, standards, habits and distance from international capital markets may cause investors to hesitate in diversifying their portfolios internationally. Availability of information may vary greatly from one national market to another. This set of data, if available, may be hard to translate into familiar standards for comparison purpose. As a consequence, individuals invest primarily in domestic assets and by the way hold poorly diversified portfolios. Informational asymmetries may play an important role in explaining the bias towards domestic assets. Heath and Tversky (1991) show that, between two identical games with the same probability, economic agents consider riskier the game that they know the less. So investors face lower costs for gathering information on their domestic assets than on foreign assets; the bias toward domestic equity may result from asymmetric information.

The pioneered work was developed by Merton (1987). He drives a simple model of capital market equilibrium with incomplete information at the national level. It seems to be easier for a domestic investor to analyze domestic assets. Merton develops the following equation:

$$
E\left(R_{i}\right)=R+\lambda_{i}+\beta_{i}\left(E\left(R_{M}\right)-R-\lambda_{M}\right)
$$

Where $\lambda_{M}$ is the weighted average shadow cost of incomplete information over all assets in the market; and $\lambda_{i}$ is the shadow cost of incomplete information for asset $i$;

Merton (1989) shows that investors invest only on assets that they are informed about and concludes that less well known assets of firms with smaller investor bases tend to have relatively larger expected returns.

Kang and Stulz (1995) use data on foreign stock ownership 1975 to 1991 to examine the determinants of the home bias in portfolio holdings. They find that foreign investors overweight shares of large Japanese firms, manufacturing industries and firms with good accounting performance. The investors have an easy access to information about those firms.

Coval and Moskowitz (1999) examine US domestic portfolio holdings. They report that US investors tilt their portfolio holdings towards companies located near their home. They argue that this irrational behaviour arises because investors have easier access to information about local companies. Though they do not directly examine international portfolio allocations, their result suggests that information advantages and information costs will play an important role in international portfolio choices as well.

Ahearne, Griever and Warnock (2004) find that information asymmetry that owe to the poor quality and low credibility financial information in many countries cause investors to hesitate in investing in foreign markets. Results prove that foreign countries whose firms do not alleviate information costs by opting into the US regulatory environment are more severely underweighted in US equity portfolios. 
Bellalah Ma. and Aboura (2006) develop a capital asset pricing model in the case of asymmetric information and transaction costs. They extend the model of Merton (1987) and Black (1974). The authors show that in equilibrium the market portfolio will not be efficient in the presence of information costs and transaction costs, which explain the home bias equity.

$$
E\left(R_{i}\right)=R+\lambda_{i}+\beta_{i M}\left(E\left(R_{M}\right)-R-\lambda_{M}\right)+\beta_{i e}\left(E\left(R_{e}\right)-R\right)
$$

where

$$
\left\{\begin{array}{l}
\beta_{i M}=\frac{\operatorname{var}\left(R_{e}\right) \operatorname{cov}\left(R_{i}, R_{M}\right)-\operatorname{cov}\left(R_{M}, R_{e}\right) \operatorname{cov}\left(R_{i}, R_{e}\right)}{\operatorname{var}\left(R_{M}\right) \operatorname{var}\left(R_{e}\right)-\operatorname{cov}\left(R_{M}, R_{e}\right)^{2}} \\
\beta_{i e}=\frac{\operatorname{var}\left(R_{M}\right) \operatorname{cov}\left(R_{i}, R_{e}\right)-\operatorname{cov}\left(R_{M}, R_{e}\right) \operatorname{cov}\left(R_{i}, R_{M}\right)}{\operatorname{var}\left(R_{M}\right) \operatorname{var}\left(R_{e}\right)-\operatorname{cov}\left(R_{M}, R_{e}\right)^{2}}
\end{array}\right.
$$

The empirical results show that the large firms are better known by investors, so investors overweight their portfolios with assets from large firms and hesitate to invest in smaller firms that are perceived as risky.

Amalgamating the above evidence implies that asymmetric information plays an important role in decision making. In fact, when investing abroad, agents have to pay costs in order to get information about foreign companies. These costs reduce benefits of international diversification. Then, since they are familiar with the domestic markets and they can get information about local companies with lower costs, usually investors manifest a preference to national diversification. Other studies tried to develop models including human capital in order to see its impact in portfolio choices. The next paragraph presents the role that may play the human capital in explaining the home bias.

\subsubsection{Human capital}

Another studies tried to test the effect of human capital in asset allocations. Baxter and Jermann (1997) focus on the role of human capital in solving the equity home bias puzzle. They do not propose an explanation for the equity home bias, but they argue that the divergence between optimal portfolios and served portfolios is much higher than is anticipated. Their motivation comes from the observation that, for a nation, the nontraded human capital is the largest component of wealth. They argue that since return to human capital is highly correlated with the return to domestic marketable assets, the domestic equity market can be used to hedge the risk associated with non traded human capital. Baxter and Jermann (1997) use American data to explore the implication of non traded human capital for the optimal portfolio of prototypical American investor. They proxy the returns on human capital by a bi-variate time-series analysis of labor and capital income and assume stationarity of the labor share of income in the long run. Results show that the returns on human capital correlate with returns on domestic assets for Japan, Germany, United Kingdom and the United States. This implies that in order to hold diversified portfolio, individuals need a short and not long position in domestic market assets.

Coen (2001) developed an international capital asset pricing model in continuous time including the human capital. He studied optimal portfolio compositions and examined if the investors reticence to international portfolio diversification can be explained by the human capital. The author extended Adler and Dumas (1983)'s model and finds that the optimal portfolio can be written as follow:

$$
\underline{w}=\frac{\alpha}{(1-\eta)}\left[\begin{array}{c}
\left.\Omega^{-1} \underline{(\mu}-r \underline{1}\right) \\
1-1^{\prime} \Omega^{-1}(\underline{\mu}-r \underline{1})
\end{array}\right]+\frac{(1-\alpha)}{(1-\eta)}\left[\begin{array}{c}
\Omega^{-1} \underline{\omega} \\
1-\underline{1}^{-1} \underline{\omega}
\end{array}\right]-\frac{\eta}{(1-\eta)}\left[\begin{array}{c}
\Omega^{-1} \underline{k} \\
1-\underline{1} \Omega^{-1} \underline{k}
\end{array}\right]
$$

Where $\underline{w}=\left\{w_{i}\right\}$ is the, $N \times 1$, vector whose components sum to 1 and which indicates the investor's portfolio choice among the available investment opportunities and it represents the nominal wealth of the investor. $\alpha$ is the investor's risk tolerance. Each investor is assumed to receive $(1-\eta)$ of his total income from financial incomes and $\eta$, from income related to human capital. $\underline{1}$ is an $N \times 1$ vector of ones, $\underline{1}$ its transpose, $\underline{\mu}$ the vector of nominal expected returns $\mu_{i}, \Omega$ the $N \times N$ matrix of instantaneous covariances $\sigma_{i, k}$ of the nominal rates of return on the various securities, $\underline{\omega}$ the $N \times 1$, vector of covariances, of the $\mathrm{N}$ risky securities returns with the investor's rate of inflation and $\underline{k}$ the vector, $N \times 1$, of covariances $\sigma_{i, h}$ of the $N$ risky securities returns with the investor's rate of change of the wage (labor income).

Coen (2001) proves that every investor in the world holds a combination of the universal logarithmic portfolio with weight $\frac{\alpha}{(1-\eta)}$, his personalized hedge portfolio which constitutes the best protection against inflation as he 
perceives it with the weight $\frac{(1-\alpha)}{(1-\eta)}$ and the personalized hedge portfolio, which constitutes the best protection against changes in the wage for the $l$ th investor with the weight $\frac{\eta}{(1-\eta)}$.

Then, the author tests whether the human capital and the hedge against inflation could explain the home bias. The results show that the human capital, with wage as a proxy, is far from being the only explanation to this puzzle. In fact, he confirmed that human capital, with labour income, as a proxy, in an international capital asset pricing model seems to be unable to explain the home bias and suggests that it would be interesting to use other proxies for human capital (age, diploma...) and to use other non-traded assets to explain the home bias observed and he suggests that the effect of asymmetric information can explain better this phenomenon.

4. Limits of the traditional theory in explaining investors' decision making

Capital asset pricing models present some limits related to both components of capital asset pricing models (capital market portfolio, the riskless asset and the beta) and investor behaviour. In this paragraph we will try to develop some of these anomalies to understand why the traditional theory may fail in explaining how financial decisions are truly made.

\subsection{Anomalies related to capital asset pricing models}

\subsubsection{Capital market portfolio}

The capital asset pricing model is used to evaluate portfolio performance. Thus it is necessary to select a proxy for the market portfolio. At the national level, the domestic market portfolio is a portfolio that includes all the risky securities in a proportion of their market value. At the international level, the world market portfolio is a portfolio that includes all the domestic market portfolios or a basket of assets representing a domestic market such as NYSE in a proportion of their market capitalization. Empirical researches generally use a broad-based equity index to proxy the market. However, this portfolio cannot be easily determined. Roll (1977) criticized the usefulness of such portfolio because the market portfolio contains other financial assets such as bonds as well as non-financial assets such as real estate, durable goods etc. Consequently, the capital asset pricing model cannot be empirically tested. In addition, the CAPM is verified when the market portfolio is efficient. However, Roll claims that if the portfolio chosen as proxy of the market portfolio is not efficient, the CAPM is the rejected and the determination both systemic and specific risk weights of a portfolio cannot be done correctly.

\subsubsection{Available risk-free assets}

The CAPM assumes the existence of a risk-free asset. The proxy of this asset is generally government bills. However, proxy assets have various risks (Alan 2005):

- $\quad$ reinvestment risk: investors may have investment horizons beyond the T-bill maturity date;

- $\quad$ inflation risk: fixed returns may be devalued by future inflation;

- $\quad$ currency risk: the purchasing power of fixed returns may diminish compared to that of other currencies.

\subsubsection{Beta as a measure of risk}

The measure of the contribution of the risk of a security to the risk of the market portfolio is the security's beta coefficient. The beta coefficient reflects then the sensivity of an asset expected return relative to market return changes. In addition, the CAPM theory assumes that the beta is the only one factor representing the risk. However, investors face other risks such as inflation risk, liquidity risk etc. Moreover, in the CAPM the beta is assumed to be the only factor causing expected return to change. However, firm size, book-to-market ratios, P/E ratios and dividend yields among other variables can explain ex-post realised returns. Moreover, Kenneth and French discuss whether market betas explain market returns.

Fama and French (2004) review the history of empirical work about shortcomings of the CAPM that pose challenges to be explained by alternative models. They find that the relation between beta and average return is flatter than predicted by the Sharpe-Lintner version of the CAPM. They conclude that the empirical record of the CAPM is poor and the empirical problems may reflect theoretical failings. They add that this may be the result of both many simplifying assumptions and difficulties in implementing valid tests of the model.

\subsection{Anomalies related to investors' behaviour}

Capital asset pricing models are based on two restrictive assumptions namely, markets efficiency and individual rationality. These two hypothesis are inconsistent with the reality and do not explain why asset prices deviate 
from the fundamental value and how financial decisions are truly made. We first show the limits to arbitrage and then the investor psychology.

\subsubsection{Limits to arbitrage}

Asset pricing models are based on market efficiency. This hypothesis is thought to be true because of arbitrage forces. However, investors can cause asset prices to deviate from their fundamental values. The later are obtained according to models based on perfect markets. According to Ritter (2003) misvaluation can be caused by temporary supply and demand imbalances. At this case, "arbitrageurs" can take positions (shorting overvalued stocks or buying undervalued stocks) to correct the misevaluations. However arbitrage is limited, since irrationality can have a substantial and long lived impact on prices. Investors face two risks: i) The fundamental risk: when buying an undervalued asset, a piece of bad news about the asset fundamental value causes the price to fall further, leading to losses, ii) The noise trader risk: the noise trader risk is introduced by De Long and al. (1990) and Shleifer and Vishny (1997). It is the risk that pessimistic investors causing the asset prices to be undervalued become even more pessimistic, lowering its price even further.

\subsubsection{Psychology}

In perfect framework, investors are supposed to be completely rational. Brav and Heaton (2002) define rationality as the ability of investors to make optimal statistical decisions in a world about which they have all relevant structural knowledge. However, Thaler (1993) shows that individuals are subject to behavioural biases, therefore, they cannot be process available information rationally. Brav and Heaton (2002) prove that experiment results document that investors react irrationally despite having considerable knowledge about the fundamental structure of the economy. In addition, from the theory of limited arbitrage, irrational traders cause deviations from fundamental value. Behavioural finance often assumes specific form of irrationality. In this framework, economists turn to the experimental evidence compiled by psychologists. To make decisions economists show investor practices that are:

- Overconfidence: Overconfidence means that individuals believe and overestimate their capacities, knowledge and future without taking into account the eventual risks. De Bondt and Thaler (1995) consider that "the most robust finding in the psychology of judgment is that people are overconfident". It is known by self-attribution bias which means that individuals attribute success to their talents and judgements and failure to bad luck or external factors (Fishhoff, Solvic and Lichtenstein (1997)).

- Optimism: Optimism can be defined as hopefulness about the future and the outcomes of events and confidence on capacities and knowledge. Montier (2002) considers that the over-optimism results from a number of psychological biases, such as the illusion of control and self-attribution bias.

- $\quad$ Representativeness: Kahneman and Tversky (1974) show that people use the representativeness heuristic to determine the probability that a data set A is generated by a model B. However, representativeness generates two severe biases: the base rate neglect and the sample size neglect.

- Concervatism and confirmation: Among available information, agents give more attention and weight to those that confirm their beliefs. Face to new information, individuals become reticent to change their beliefs and rely too much on their priors. Ritter (2003) considers that when things change, people might underreact because of the conservatism bias. However, if there is a long enough pattern, then they will adjust to it and possibly overreact, underweighting the long-term average.

- Anchoring: Kahneman and Tversky (1974) argue that when forming estimates individual starts firstly with some initials and then adjust away from it.

- Belief perseverance: Lord, Ross and Lepper (1979) show that after forming an opinion, individuals cling to it for too long. Generally they avoid searching for evidence that contradicts their beliefs and even they find such evidence they treat it with skepticism.

- Availability biases: Kahnman and Tversky (1974) consider that when forming estimates, people often start with looking for some initials, instances or occurrences brought in mind rather than examine other procedures or alternatives. However availability leads to predictable biases: Familiarity bias, Effectiveness of a search set, Imaginability bias and Illusory correlation.

- Mental accounting: Thaler (1985) defines mental accounting as a kind of narrow framing that involves keeping track of gains and losses related to decisions in separate mental account, and to re-examine each account only intermittently when action relevant. 
- Emotions and affects: In financial analysis of choice under uncertainty, investors are supposed to be rational and behave according to a number of basic axioms formulated by Von Newman and Morgenstern (1974). They are supposed to maximise their utility function in a risky and uncertain environment. However, the observed behaviour of many people violates these axioms namely the expected utility theory. Emotions and affects have important impacts in the reasoning process. Individuals rely on sentiments when making judgements and taking decisions. Funcane and al (2000) find that there is an inverse relationship between perceived risk and perceived benefits. They explain this relationship by the fact that people rely on affect when judging the risk and benefits of specific hazards.

\section{Conclusion}

It is well documented that international portfolio diversification does better than the diversification at the national level. When there are no barriers to international portfolio investments and where investors in all over the world are assumed to be the same, they hold the same portfolio of risky assets, namely the global market portfolio. Adding the hypothesis of market clearing, domestic investors of each country of the world should hold portfolio in which its country shares are equal to its shares in world market capitalization. However, agents still overweight their portfolios with the domestic assets. When examining the home bias in seventeen developed markets and twenty-two emerging markets from 1996 to 2007, results show that most countries have important bias which is in most cases near to $100 \%$. The United States and the United Kingdom represent the lowest home bias but it remains so far from the optimal allocation and investors still manifest a reticence to international diversification.

Many researchers tried to explain this puzzle using traditional framework based on restrictive assumptions. In this paper we present an integrative survey of market imperfections in an international portfolio asset allocation. We presented some explanations for this phenomenon based on international asset pricing models and market imperfections. Several factors seem to provide explanations for this bias, such as exchange rate risk, inflation risk, taxes, transactions costs, human capital, market restrictions and the effect of asymmetric information. These market frictions provide some explanations regarding how markets are segmented or mild-integrated or/and integrated but, up to now, no model gives an exact explicit value of the degree of market integration or segmentation.

Moreover, traditional finance paradigm is limited. In fact, misvaluations observed in capital markets cannot be explained by such simple framework. Firstly, many authors criticise components of capital, namely, the market portfolio, the riskless asset and the beta as the measure of risk. They show that the proxies of these parameters have various risks. In addition, the traditional financial theory assumes that markets are efficient and investors are rational, but the evidence show that individuals are subject to behavioural biases. As a response to these difficulties, behavioural finance has emerged to show that some financial phenomena can plausibly be understood by using models where agents are not fully rational. The explanations of the international diversification puzzle by behavioural finance remains a question for future research.

\section{References}

Ackert L., Church B. \& Engils B. (2002). The asset allocation decision \& investor heterogeneity: a puzzle? Journal of Economic Behaviour and Organization, vol. 47, pp. 423-433.

Adler M. \& Dumas B. (1983). International Portfolio Choice and Corporation Finance: A Synthesis. The Journal of Finance, vol. 38, n 3, pp. 925-984.

Alain Coen (2001). Home bias and international capital asset pricing model with human capital. Journal of Multinational Financial Management, Volume 11, Issues 4-5, December 2001, pp. 497-513.

Alan (2005). Low \& Valuation, Financial Valuation in legal contexts. Wake Forest University School of Low.

Alan A., William L. Griever \& Francis E. Warnock (2004). Information costs and home bias: An analysis of U.S. holdings of foreign equities. Journal of International Economics, vol. 62, issue 2, pp. 313-336.

Alan R. P. (2005). Low and Valuation, Financial Valuation in legal contexts. Wake Forest University School of Low.

Arouri M.H. (2005). Intégration financière et diversification internationale des portefeuilles. Economie et Prévisions, n 168/2, pp. 115-132.

Baxter, Marianne, \& Urban J. Jermann (1997). The International Diversification Puzzle is Worse Than You Think. American Economic Review, vol. 87, pp. 170-18. 
Bellalah Ma. \& Aboura S. (2006). The Effect of Asymmetric Information and Transaction Costs on Asset Pricing : Theory and Test. International Journal of Business, ,vol. 2, n 11 , pp. 182-198.

Bellalah Ma. \& Bellalah Mo. (2006). The equity home bias: an explanation. Banques et Marchés.

Bellalah Ma. (2001). An International Asset Pricing Model with Constraints on Equity Ownership. Cahier de recherche, n 2002-04, Paris Dauphine.

Benoît Carmichael \& Alain Coën (2003). International Portfolio Choice in an Overlapping Generations Model with Transaction costs. Economic Letters, vol. 80, n 2, pp. 269-275.

Black. F. (1974). International capital market equilibrium with Investment barriers. Journal of Financial Economics, vol. 1, pp. 337-352.

Brav A. \& Heaton J. B. (2002). Competing theories of financial anomalies. The Review of Financial Studies, vol. $15, \mathrm{n}^{\circ} 2$, pp. 575-606.

Coen Alain. (2001). Home bias and International Capital Asset Pricing Model with Humain Capital. Journal of Multinational Financial Management, vol 4, n 11, pp. 497-513.

Cooper.I \& Kaplanis.K (1994). What Explains the Home Bias Equity in Potfolio Investment. The Review of Financial Studies, vol. 7, pp. 45-60.

Cosset Jean-Claude \& Suret Jean-Mark (1995). Political Risk and Benefits of international portfolio diversification. Journal of International Business Studies, vol. 26, no. 2, pp. 302-328.

Cosset, J.-C. \& J.-M. Suret (1995). Political risk and the Benefits of International Diversification. Journal of International Business Studies, vol. 26, $\mathrm{n}^{\circ}$ 2, pp. 301-318.

Coval J. \& Moskowitz T. (2000). Home Bias at Home: Local Equity Preference in Domestic Portfolios. Journal of Finance, vol. 54, n 6 , pp. 2045-2073.

De Bondt W. \& Thaler R. (1995). Financial decision-making n markets and firms: A behavioural perspective. NBER working paper series $N^{\circ} 4777$.

De Santise G. \& Bruno G. (1997). International Asset Pricing and Portfolio Diversification with Time- varying Risk. Journal of Finance, vol. 52, p1881-1912.

Erb C., Harvey C. \& Viskanta T. (1996). Political Risk, Economic Risk, and financial Risk. Financial Analysis Journal, November/December 1996, pp. 29-46.

Errunza V. R. \& Losq E. (1985). International Asset Pricing under Mild Segmentation: Theory and Tests. Journal of Finance, vol. 40, pp. 105-144.

Errunza V.R. (1977). Gains from portfolio diversification into less developed countries securities. Journal of International Business Studies, Fall-Winter, pp. 83-99.

Erruza V. R. \& Losq E. (1989). Capital Flow Controls, International Asset Pricing, and Investor's Welfare: A Multi-country Framework. Journal of Finance, vol. 44, pp. 1025-1037.

Eun C. S. \& Janakiramanan. (1986). A model of international asset pricing model with constraint on the foreign equity ownership. The Journal of Finance, vol. 41, n 4, pp. 897-914.

Fama E. F. \& French K. R. (2004).The Capital Asset Pricing Model: Theory and Evidence. Journal of Economic Perspectives, Vol. 18, N³, pp. 25-46.

Fishhoff, Solvic. \& Lichtenstein. (1997). Knowing with Certainty: The Appropriateness of Extreme Confidence. Journal of Experimental Psychology: Human Perception and Performance, Vol. 3, pp. 552-564.

French K. \& Poterba J. (1991). Investor Diversification and International Equity Markets. American Economic Review. Vol.81, pp.222-226.

Funcane L., Alhakami A., Solvic P. \& Johnson M. (2000). The affect heuristic in judgments of risks and benefits. Journal of Bahavioural Decision Making, vol. 13, p1.

Grauer F. L. A., Litzenberger R. H. \& Stehle R. E. (1976). Sharing rules and equilibrium in an international market under uncertainty. Journal of Financial Economics, vol. 3, n 3, pp. 233-256.

Heath C. \& Tversky A. (1991). Preference and belief: Ambiguity and competence in choice under uncertainty. Journal of Risk and Uncertainty, vol.4, pp. 5-28. 
Hietala P. T. (1989). Asset pricing in Partially Segmented Markets: Evidence From the Finish Market. The Journal of Finance, vol. 44, n 3, pp.697-719.

Kahneman D. \& Tversky A. (1974).Judgement Under Uncertainty: Heuristics and Biases. Science, vol. 185, pp. 1124-1131.

Kang. J. \& Stulz. R (1997). Why is there a home bias? An Analysis of Foreign Portfolio Equity in Japan. Journal of Financial Economics, pp.4-28.

Lewis. K. (1999). Trying to Explain Home Bias in Equities and Consumption. Journal of Economic Literature, p.571.608.

Lich Amir N. (2001). Regulatory arbitrage for real: International security regulation in a world of increasing security markets. Virginia Journal of International Law, vol. 38, pp. 563-636.

Lord C., Ross L. \& Lipper M. (1979). Biased assimilation and attitude polarization: The effect of prior theories on subsequently considered evidence. Journal of Personality and Social Psychology, vol. 37, pp. 2098-2109.

Merton R. (1987). An equilibrium Market Model with Incomplete Information. Journal of Finance, vol. 42, n 3 , pp. 483-510.

Montier J. (2002). Behavioural finance. copyright 2002 John Wiley and sons Ltd, Collection: Wiley Finance Series.

Obsfeld M. \& Kenneth R. (2000). Six Major Puzzles in international macroeconomics: Is there a common cause? National Bureau of Economic Research, Working paper 7777.

Ritter J. R. (2003). Behavioural Finance. Pacific-Basin Finance Journal, vol. 11, pp. 429-437.

Roll Richard. (1977). A Critique of the Asset Pricing Theory's Tests' Part I: On Past and Potential Testability of the Theory. Journal of Financial Economics, vol. 4, pp. 129-76.

Sercu P. (1980). A Generalisation of the International Asset Pricing Model. Revue de l'Association Française de Finnance, vol. 1, pp.91-135.

Shleifer A. \& Vishny R. (1997). The Limits of Arbitrage. Journal of Finance, Vol. 52, pp. 35-55.

Solnik B. (1974). An Equilibrium Model of international Capital Market. Journal of Economic Theory, vol. 8, ${ }^{\circ}$ 4, p 500-524.

Stulz R. (1981a). A Model of International asset pricing. Journal of Financial Economics, vol. 9, $\mathrm{n}^{\circ} 4$, pp.383-406.

Stulz R. (1981b). On the effect of barriers to international investment. Journal of Finance, vol. 36, pp.923-934.

Stulz, R.M. \& Wasserfallen W., (1995). Foreign equity investment restrictions, capital flight, and shareholder wealth maximization: Theory and evidence. The Review of Financial Studies, vol. 8, pp. 1019-1057.

Tesar L. \& Werner I. (1995). Home Bias and High Turnover. Journal of International Money and Finance, vol.14, pp. 467-492.

Thaler (1985) in Hirshleifer D. (2001), "Invetor psychology and asset pricing", The journal of Finance, vol.56, $\mathrm{n}^{\circ} 4$, pp. 1533-1597.

Thaler, R. H. (ed.), (1993). advances in behavioural Finance. Russel Sage, New York.

Vassalou M. (2000). Exchange rate and foreign inflation risk premiums in global equity returns. Journal of International Money and Finance, vol. 19, pp. 433-470.

Appendix. The Equity Home Bias in the World

Appendix 1 . The equity home bias in the developed countries 
Developed American countries

Graph 1 . The Equity home bias in

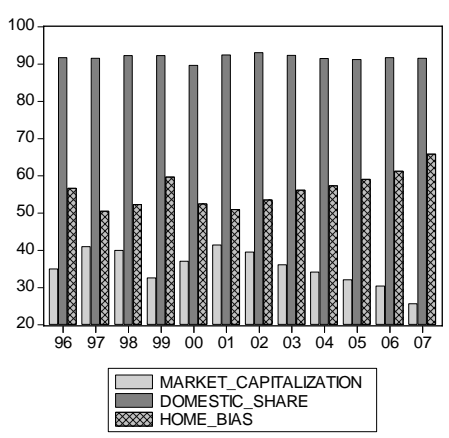

The United States

\section{Developed European countries}

Graph 4 . The equity home bias in France

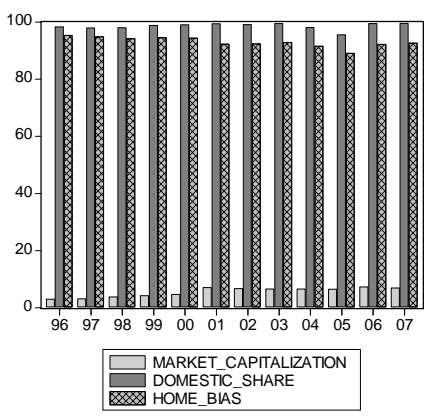

Graph 7. The equity home bias in Italy

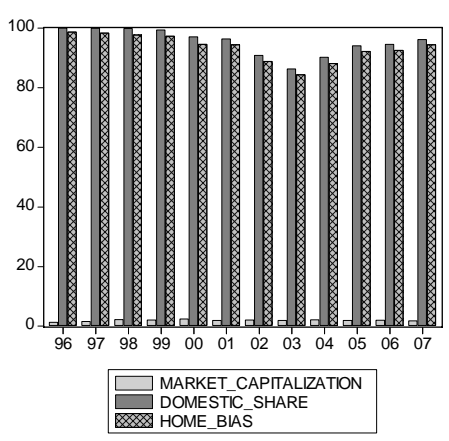

Graph 2. The Equity home bias in Canada

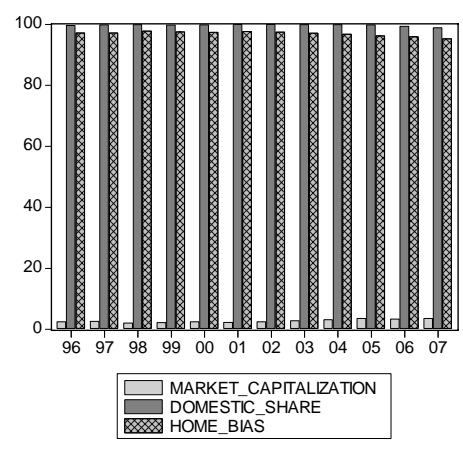

Graph 5 . The equity home bias in Germany

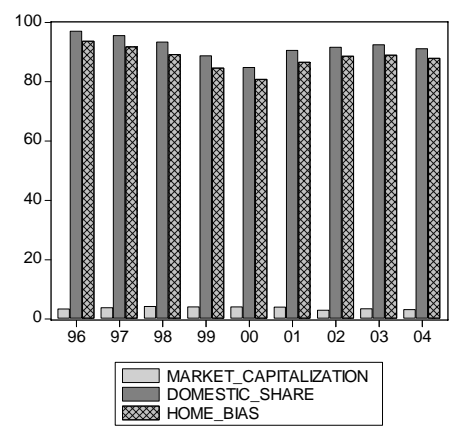

Graph 8 . The equity home bias in Ireland

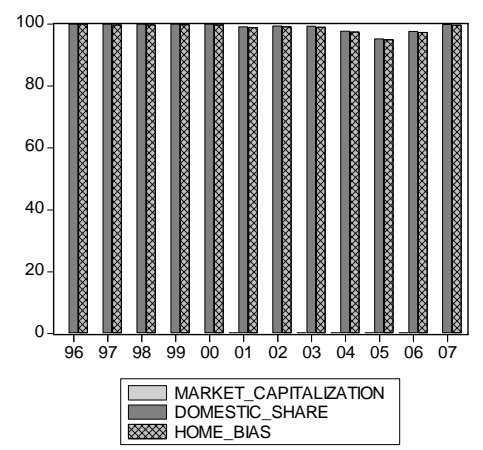

Graph 3. The equity home bias in the United Kingdom

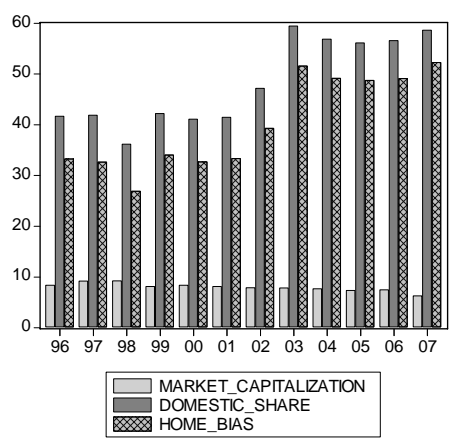

Graph 6. The equity home bias in Greece

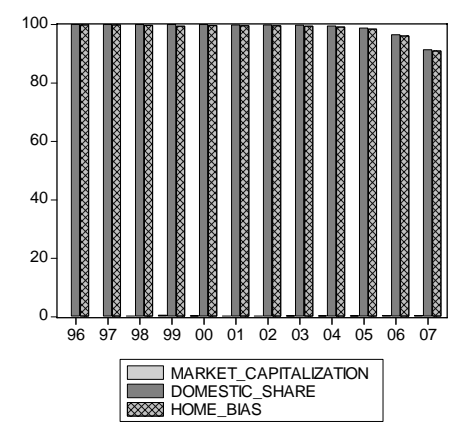

Graph 9. The equity home bias in Spain

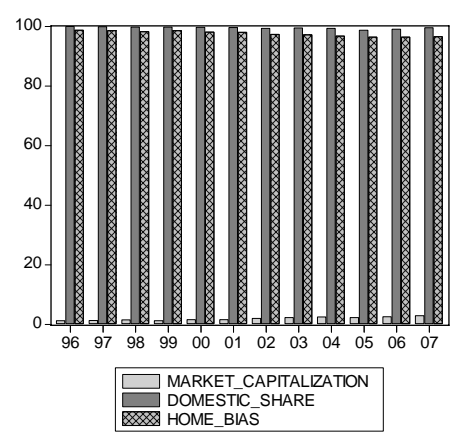


Graph 10. The equity home bias in Finland

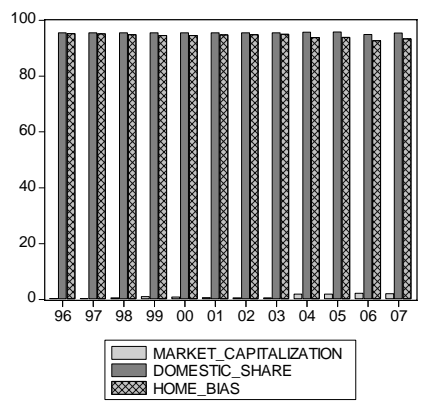

\section{Developed Asian countries}

Graph 13. The equity home bias in Japan

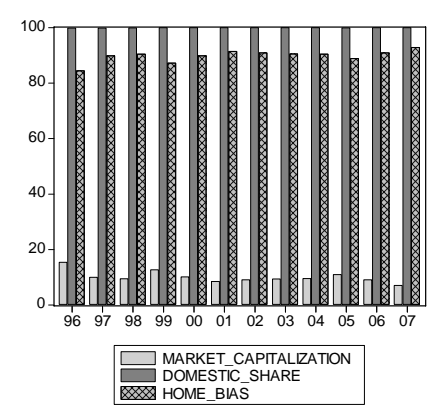

Graph 16. The equity home bias in Australia

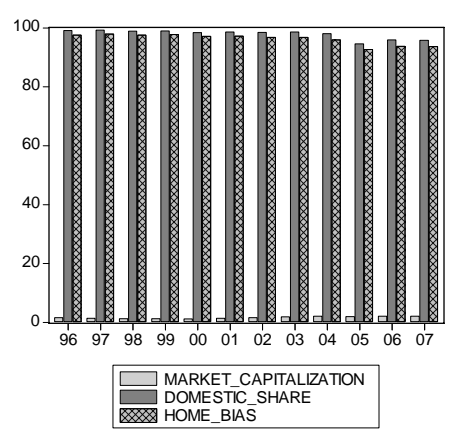

Graph 11. The equity home bias in Luxembourg

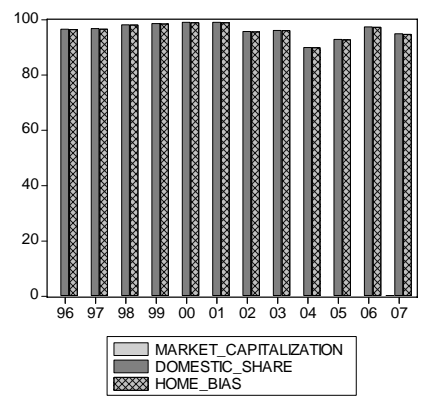

Graph 14. The equity home bias in Singapore

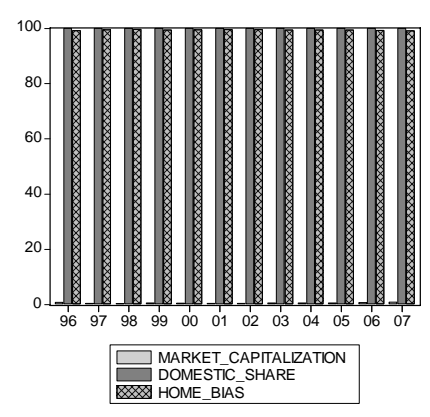

Graph 17 . The equity home bias in New Zeeland

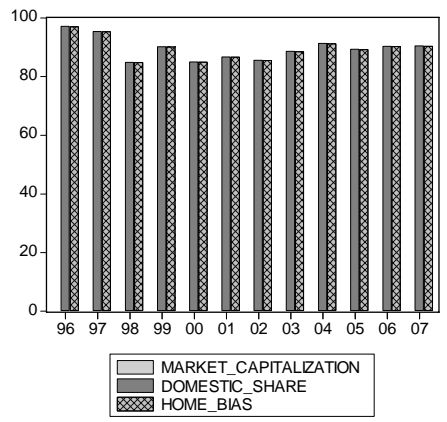

Graph 12. The equity home bias in Norway

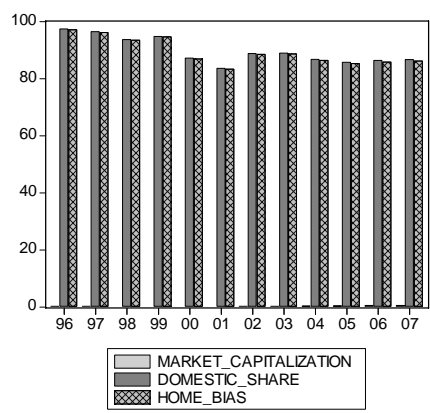

Graph 15. The equity home bias in Hong Kong

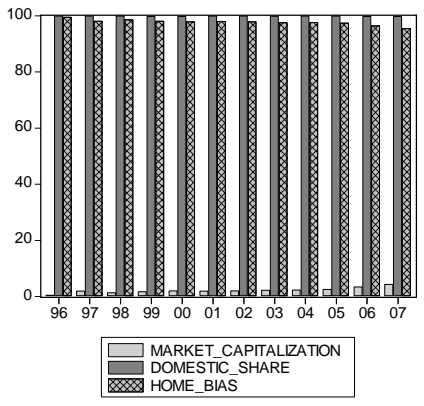


Appendix 2 The equity home bias in the emerging countries

Emerging American countries

Graph 18. The equity home bias in

Argentina

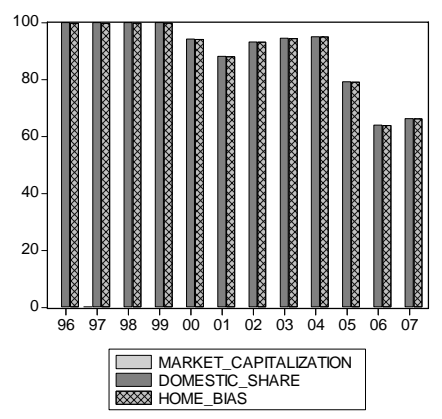

Graph 21. The equity home bias in Chile

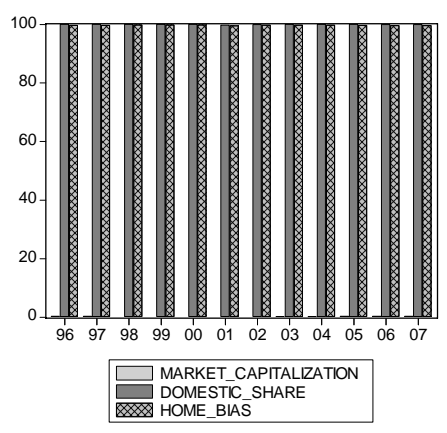

\section{Emerging European countries}

Graph 23. The equity home bias in Hungary

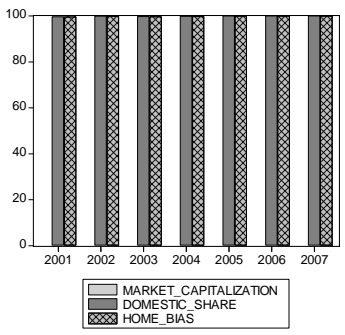

Graph 19. The equity home bias in Brazil

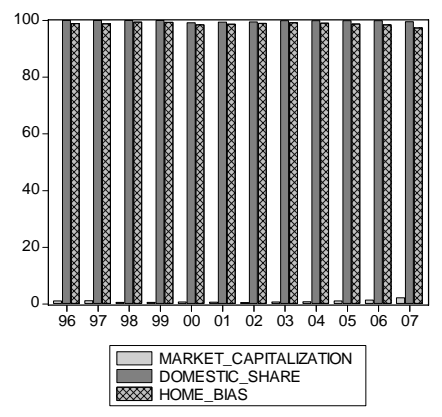

Graph 22. The equity home bias in Peru

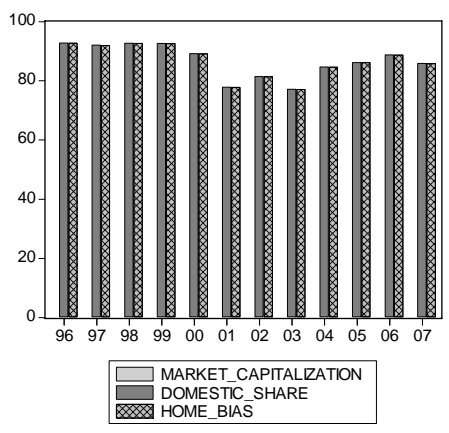

Graph 24. The equity home bias in Polan

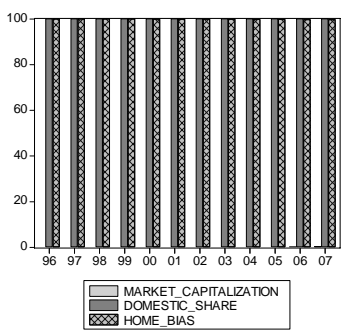

d
Graph 20. The equity home bias in Mexico

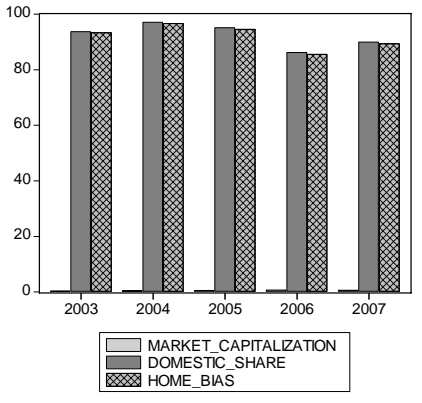

Graph 25. The equity home bias in Slovenia

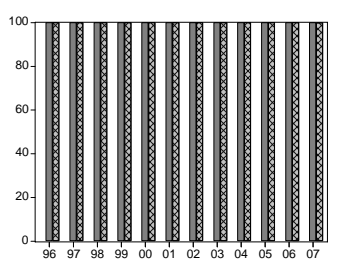


Graph 26. The equity home bias in Cyprus

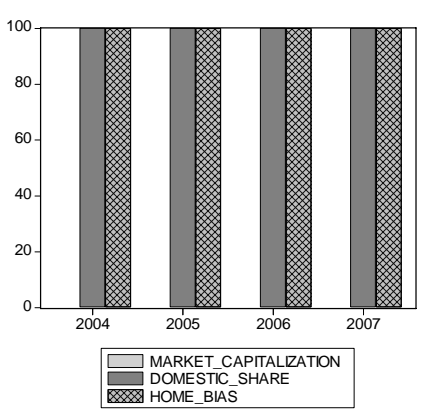

\section{Emerging Asian countries}

Graph 28. The equity home bias in China

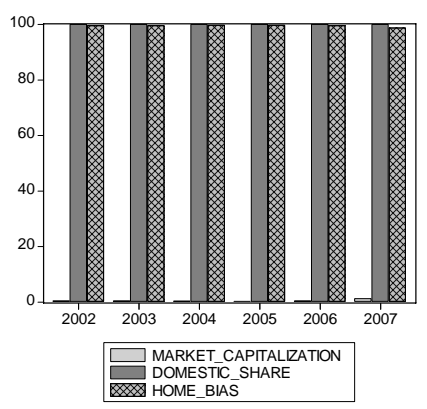

Graph 31. The equity home bias in Sri Lanka

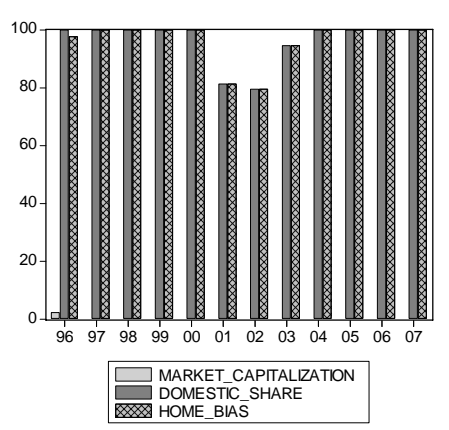

Graph 27. The equity home bias in Istanbul

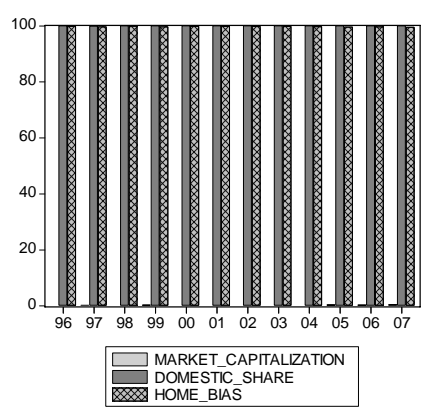

Graph 29. The equity home bias in India

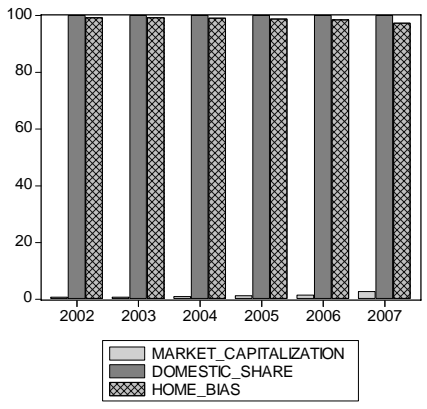

Graph 32. The equity home bias in Taiwan

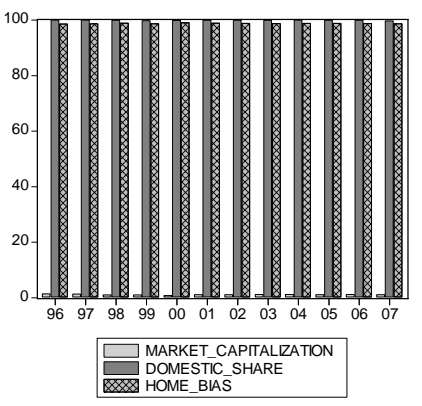

Graph 30. The equity home bias in Malaysia

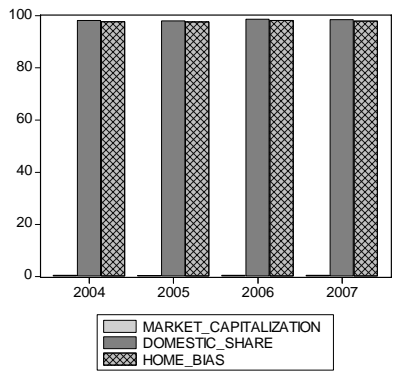

Graph 33. The equity home bias in Thailand

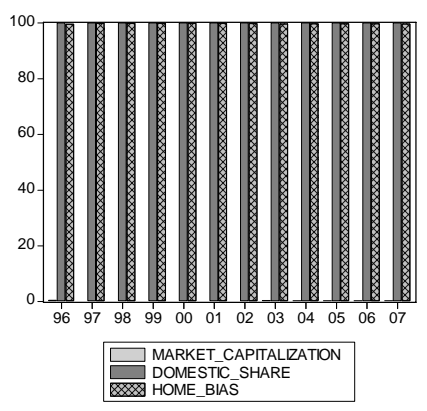


Graph 34. The equity home bias in Philippine

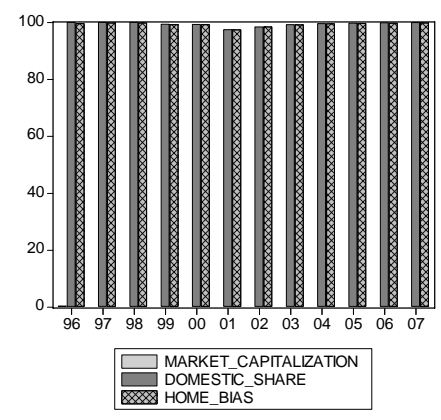

Graph 37 . The equity home bias in Israel

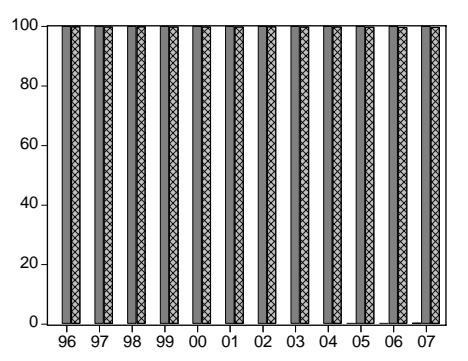

MARKET_CAPTALZATION
DOMESTIC SHARE HOME_BAAS

\section{Emerging African Countries}

Graph 38: The equity home bias in Egypt

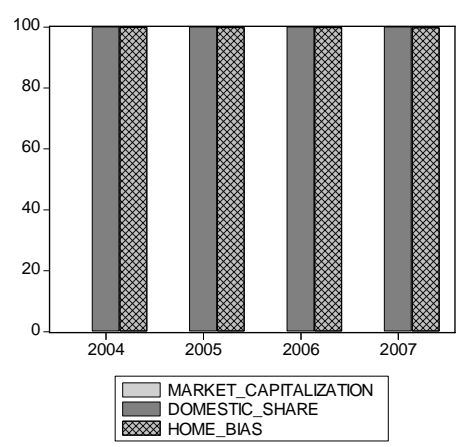

Graph 36 . The equity home bias in Tehran

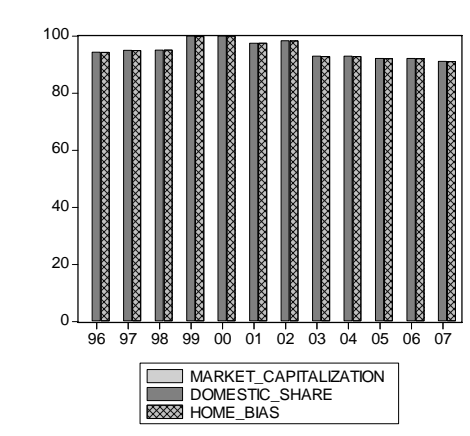

Graph 35. The equity home bias in Korea

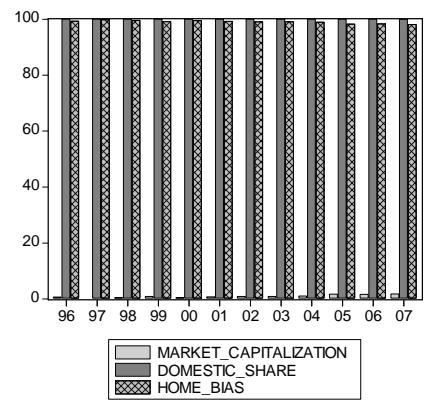

Graph 39. The equity home bias in South Africa

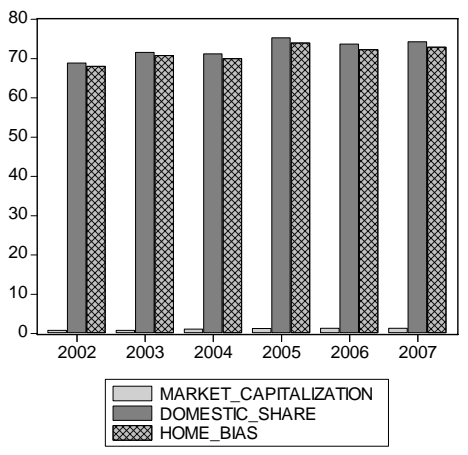

